\title{
Effect of Activated Sludge Process and Sludge Storage on Removal of Escherichia coli $0157: \mathrm{H} 7$
}

\author{
SHIGERU TAKEDA*1, SETSUKO KITAHARA*2, and KEISUKE IWAHORI*3 \\ ${ }^{* 1}$ Department of Life Environment, Kanagawa Pref. Public Health Laboratory \\ /1-1-1, Nakao, Asahi-ku, Yokohama 241-0815, Japan \\ ${ }^{* 2}$ Department of Environmental Sciences, Otsuma Women's University \\ /2-7-1, Karakida, Tama, Tokyo 206-8540, Japan \\ ${ }^{* 3}$ Institute for Environmental Sciences, University of Shizuoka \\ /52-1, Yada, Shizuoka 422-8526, Japan
}

\begin{abstract}
An experimental investigation was carried out on removal characteristics of Verotoxin-free Escherichia coli 0157:H7 in a batch culture of activated sludge and stored sludge, and then its profiles in a domestic wastewater treatment facility was discussed.

Domestic wastewater containing about $10^{4} \mathrm{CFU} / \mathrm{m} l$ of $E$. coli $0157: \mathrm{H} 7$ was treated by activated sludge (MLSS concentration was about $2,500 \mathrm{mg} / l$ ) at $25^{\circ} \mathrm{C}$. E. coli $0157: \mathrm{H7}$ was almost completely removed from the supernatant after $8 \mathrm{hrs}$, and fecal coliforms and total coliforms were reduced considerably. Although the bacteria in the activated sludge mixed liquor decreased with aeration time, $E$. coli $0157:$ H7 still survived after 24 hrs. $E$. coli $0157: \mathrm{H7}$ was almost all removed from the stored sludge after 30 days while for fecal coliforms and total coliforms it took up to 150 days for removal.

We proposed a case study model for $E$. coli 0157:H7 removal in a middle-scale domestic wastewater treatment facility using the extended aeration process where the bacterial contamination occurs at the level of $10^{4} \sim 10^{5} \mathrm{CFU} / \mathrm{m} l$. The number of $E$. coli $0157: \mathrm{H7}$ bacteria declines in the aeration tank during the $24 \mathrm{hr}$ aeration period and is almost completely removed from the resulting biologically treated water. If $0.5 \%$ of influent is taken from the sedimentation tank as excess sludge, $E$. coli $0157: \mathrm{H} 7$ survives in this sludge at the level of $10^{2} \sim 10^{3} \mathrm{CFU} / \mathrm{ml}$. The bacteria in the sedimentary sludge increases by thickening but is almost completely removed during storage over a month.
\end{abstract}

Key words : Escherichia coli $\mathrm{O} 157: \mathrm{H} 7$, coliforms, domestic wastewater, activated sludge, sludge storage

\section{INTRODUCTION}

Escherichia coli responsible for diarrhea is classified into Enteropathogenic E. coli, Enterotoxigenic $E$. coli, Enteroinvasive $E$. coli and Enterohemorrhagic E. coli. Pathogenic E. coli $\mathrm{O} 157: \mathrm{H} 7$, by which food poisoning has often occurred in Japan, resulting in an increasing number of deaths ${ }^{1)}$, belongs to Enterohemorrhagic $E$. coli and is taxonomically expressed " $E$. coli $0157: \mathrm{H} 7$,
$\mathrm{VT}(+)$ " because of producing Verotoxin of a strong toxicity.

In Japan, an outbreak of food poisoning by pathogenic $E$. coli is immediately followed by preventive measures against the specially designated communicable diseases. However, in most cases, pathogenic E. coli excreted from those infected has already entered sewers or domestic wastewater treatment facilities such as Johkasou, before being detected as a pathogen of the food poisoning. 
As for the fate of pathogenic microorganisms in wastewater or sludge treatment process, some reports have been made on Vibrio cholerae $^{2), 3)}$, Salmonella ${ }^{3-7)}$ and Welchii (Clostridium perfringens) ${ }^{3)}$. The behavior or the survival of pathogenic $E$. coli $0157: H 7$ in natural water has been reported ${ }^{8)-10)}$, but there has been little or no discussion in wastewater treatment process. Therefore, it is very significant to make an experiment to know the removal or the fate of $E$. coli 0157 : $\mathrm{H} 7$ in biological treatment processes and examine the case study model at the domestic wastewater treatment facility which is led from this experiments.

In this paper, an experimental investigation was carried out on removal characteristics of Verotoxin-free E. coli $0157: \mathrm{H} 7$ in a batch culture of activated sludge and stored sludge, and then its profiles in a domestic wastewater treatment facility was discussed from the obtained results.

\section{MATERIALS AND METHODS}

\section{Escherichia coli 0157 : H7 E. coli 0157}

:H7, VT(-) strain from Kanto Chemical co. was used in the experiments. This strain was incubated at $36^{\circ} \mathrm{C}$ for $18 \mathrm{hrs}$ in a TSB (Tripticase Soy Broth) medium (BBL/Difco). A sediment after being centrifuged(4,000 rpm, $10 \mathrm{~min}$ ) was washed several times in a

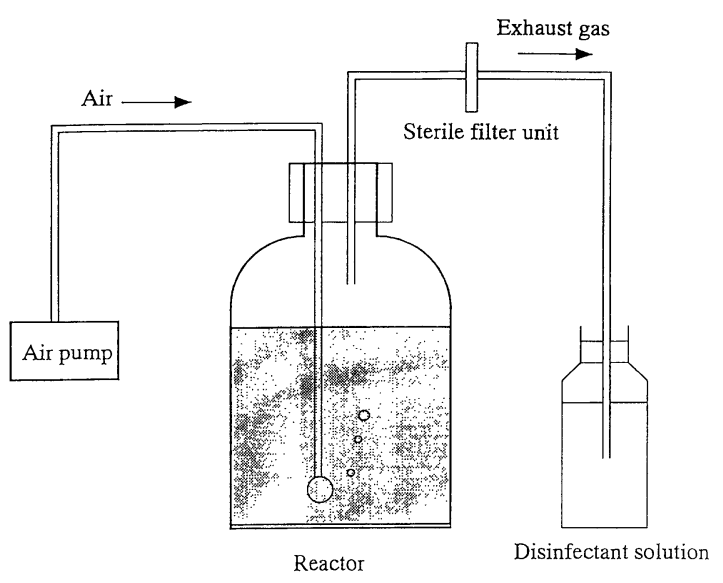

Fig. 1 Experimental apparatus. phosphate buffer (pH7.2), and was then diluted with this buffer to be approximately $10^{6}$ $\mathrm{CFU} / \mathrm{ml}$.

Activated sludge Excess sludge $(6,050$ $\mathrm{mg} / l$ of MLSS) taken from the sludge adjustment and measurement device of a gappei-shori Johkasou, was used in the experiments after being washed by deionized water. This Johkasou was designed for 3,100 users, using the extended aeration process.

Wastewater Domestic wastewater taken from the flow adjustment and measurement device of the above-mentioned Johkasou was used in the experiments, and its BOD concentration was $240 \mathrm{mg} / l$.

Experimental apparatus The shematic diagram of experimental apparatus is shown in Fig. 1, composed of a $1 l$ glass reactor. The air flowing was supplied at $0.5 \mathrm{l} / \mathrm{min}$ to the reactor. The waste air through a sterrile filter $(0.2 \mu \mathrm{m})$ was flowed to disinfectant solution. The reactor was placed in a constant-temperature $\operatorname{room}\left(25^{\circ} \mathrm{C}\right)$.

Methods Four hundreds $\mathrm{m} l$ of wastewater was added in the reactor. A fixed volume of $E$. coli $\mathrm{O} 157: \mathrm{H} 7$ or the activated sludge was inoculated into the wastewater in each Run, and then the wastewater was aerated for $24 \mathrm{hrs}$. Inoculum of RUN 1 was activated sludge, that of RUN 3 was $E$. coli O157:H7, and that of RUN 2 was both. Initial concentration of E. coli $\mathrm{O} 157: \mathrm{H} 7$ was set up about $10^{4} \mathrm{CFU} / \mathrm{ml}$. This concentration was decided from reference literature ${ }^{2), 8)}$.

And initial conditions of activated sludge were $3,000 \mathrm{mg} / l$ as MLSS in each experiment. During the aeration, about $50 \mathrm{~m} l$ of the activated sludge mixed liquor in the reactor was periodically taken for analysis. The bacteria were counted in each mixed liquor and in the supernatant obtained after settlement of the mixed liquor.

After the $24 \mathrm{hr}$ aeration period, the activated sludge mixed liquor of RUN 1 and RUN 2 was left for about $4 \mathrm{hrs}$ and the settled sludge was obtained by discarding the supernatant. The settled sludge, moved to capped $200 \mathrm{~m} l$ bottles, was left in anaerobic condition at $25{ }^{\circ} \mathrm{C}$ for 150 days. As for Run 3, the liquor was stored in anoxic condition at $25^{\circ} \mathrm{C}$. During this storage, the bacteria in the sludge (RUN 1 and RUN 2) or in the 
liquor(RUN 3) were counted periodically.

Analysis E. coli $0157: \mathrm{H} 7$ was measured with a CHROMagar O157 medium (CHROMagar co. $)^{11}$, being incubated at $42^{\circ} \mathrm{C}$ for $24 \mathrm{hrs}$. Fecal and total coliforms were counted at $36^{\circ} \mathrm{C}$ for $24 \mathrm{hrs}$ using a Chromocult Coliform Agar medium (Merck co.) ${ }^{12}$. The standard plate count bacteria were measured using a standard agar culture medium (Nissui pharm. co.) at the same condition as fecal and total coliforms.

\section{RESULTS}

Water quality and microscopic observation Although the BOD of the original domestic wastewater was $240 \mathrm{mg} / l$, that of the supernatant for RUN1 and RUN2 decreased to $7 \sim 10 \mathrm{mg} / l$ after a $24 \mathrm{hr}$ treatment with the activated sludge. But for Run 3 , the BOD was $190 \mathrm{mg} / l$ and showed little decrease, since the activated sludge had not been added. The MLSS concentration of the freshly-prepared mixed liquor for RUN1 and RUN2 ranged from 2,550 to $2,700 \mathrm{mg} / \mathrm{l}$, and that of the mixed liquor after $24 \mathrm{hr}$ aeration was almost the same. The thickened sludge, obtained by settling the mixed liquor and discarding the supernatant after the aeration experiment, was $7,650 \sim 7,800 \mathrm{mg} / l$ of MLSS. So, the mixed liquor was thickened about 3 times. The $\mathrm{pH}$ of the thickened sludge for RUN 1 and RUN2 was $6.9 \sim 7.0$ and then changed to $5.8 \sim$ 6.1 after 150 day storage. The ignition loss of thickened sludge for RUN 1 and RUN 2 was $64.5 \sim 67.7 \%$ and then changed to $57.6 \sim 58.6 \%$ after the storage.

Ciliata, Sarcodina, and Aschelminthes were microscopically observed. Namely, Epistylis sp. was by $20 \sim 25 \mathrm{~N} / \mathrm{ml}$, Aspidisca costata was by $200 \sim 220 \mathrm{~N} / \mathrm{ml}$, Litonotus $\mathrm{sp}$. was by $10 \sim$ $15 \mathrm{~N} / \mathrm{ml}$, Spirostomum sp. was by $10 \sim 12$ $\mathrm{N} / \mathrm{ml}$, Amoeba sp. was by $15 \sim 18 \mathrm{~N} / \mathrm{ml}$, Arcella sp. was by $30 \sim 36 \quad \mathrm{~N} / \mathrm{ml}$, and Philodina sp. was by $15 \sim 18 \mathrm{~N} / \mathrm{m} l$, respectively. The number of these microorganisms did not change much during the aeration. Vorticella microstoma and Chaetonotus sp. which had inhabited the aeration tank of Johkasou were not detected in this experiment.

Fate of bacteria Table 1 shows the survival of the bacteria in the supernatant obtained after settlement of the mixed liquor. E. coli O157:H7 was almost completely removed on RUN 2 after an $8 \mathrm{hr}$ aeration with the activated sludge, but definite decline was not observed on RUN 3 without the activated sludge even after a $24 \mathrm{hr}$ aeration period. Similarly, fecal coliforms and total coliforms decreased with aeration time on RUN 1 and RUN 2 where the activated sludge was added, but they did not decrease so much on RUN 3.

Table 2 shows the survival of the bacteria in the activated sludge mixed liquor on RUN 1 and RUN 2. Although a decline with time was observed for each bacteria, $7.5 \times 10^{2}$ $\mathrm{CFU} / \mathrm{m} l$ of $E$. coli $\mathrm{O} 157: \mathrm{H} 7,0.7 \sim 1.2 \times 10^{3}$ $\mathrm{CFU} / \mathrm{m} l$ of fecal coliforms, and $6.5 \sim 9.2 \times 10^{3}$ $\mathrm{CFU} / \mathrm{m} l$ of total coliforms still survived even after a $24 \mathrm{hr}$ aeration period.

Table 3 shows the survival of the bacteria over a 150 day period in the stored sludge following the $24 \mathrm{hr}$ aeration process. Escherichia coli 0157:H7 whose initial concentration was $1.4 \times 10^{3} \mathrm{CFU} / \mathrm{ml}$ was almost completely removed after 30 days on RUN 2, and $3.4 \times 10^{4} \mathrm{CFU} / \mathrm{m} l$ of $E$. coli $\mathrm{O} 157$ : $\mathrm{H} 7$ was almost completely removed after 60 days on RUN 3. Similarly, fecal coliforms and total coliforms which still survived after 90 days were removed after 150 days for all three test cases. Standard plate count bacteria, whose initial concentrations on RUN 1 and RUN 2 were at the level of $10^{7} \mathrm{CFU} / \mathrm{ml}$, decreased to $10^{6} \mathrm{CFU} / \mathrm{ml}$, while for RUN 3, the initial level of $10^{7} \mathrm{CFU} / \mathrm{m} l$ decreased to $10^{4} \mathrm{CFU} / \mathrm{m} l$ after 150 day storage.

\section{DISCUSSION}

Removal of $E$. coli 0157:H7 by activated sludge Experiments were carried out on the assumption that about $10^{4} \mathrm{CFU} / \mathrm{m} l$ of $E$. coli O157:H7 survived in an aeration tank. E. coli $\mathrm{O} 157: \mathrm{H} 7$ was removed after more than $8 \mathrm{hr}$ aeration with $2,500 \mathrm{mg} / l$ of MLSS. Figure 2 shows the relationship between aeration time and survival ratio of bacteria for RUN 2. Each bacterium in the supernatant did not grow but decreased rapidly with aeration time. Especially the survival ratio of E. coli $\mathrm{O} 157: \mathrm{H} 7$ decreased to less than $0.1 \%$ after $8 \mathrm{hrs}$, that is, more than $99.9 \%$ of $E$. coli O157:H7 was removed. Fecal coliforms and total coliforms decreased at a rate similar to 
Table 1 Survival of the bacteria in the supernatant

\begin{tabular}{rcccc}
\hline & \multicolumn{4}{c}{ Counts (CFU/ml) } \\
\cline { 2 - 5 } Time (hrs) & 0 & 3 & 8 & 24 \\
\hline E. coli O157 : H7 & & & \\
RUN 1 & N.D. & N.D. & N.D. & N.D. \\
2 & $1.2 \times 10^{4}$ & $4.0 \times 10^{2}$ & $<10$ & $<10$ \\
3 & $6.8 \times 10^{4}$ & $4.9 \times 10^{4}$ & - & $4.4 \times 10^{4}$ \\
Fecal coliforms & & & & \\
RUN 1 & $1.4 \times 10^{4}$ & $6.6 \times 10^{2}$ & $9.5 \times 10$ & $3.6 \times 10$ \\
2 & $3.7 \times 10^{4}$ & $8.5 \times 10^{2}$ & $8.0 \times 10$ & $1.0 \times 10$ \\
3 & $1.1 \times 10^{5}$ & $1.0 \times 10^{5}$ & - & $7.8 \times 10^{4}$ \\
Total coliforms & & & & \\
RUN 1 & $5.6 \times 10^{4}$ & $3.3 \times 10^{3}$ & $6.3 \times 10$ & $1.4 \times 10^{2}$ \\
2 & $7.8 \times 10^{4}$ & $5.2 \times 10^{3}$ & $3.2 \times 10^{2}$ & $4.2 \times 10$ \\
3 & $2.2 \times 10^{5}$ & $2.3 \times 10^{5}$ & - & $2.1 \times 10^{5}$ \\
\hline & & \multicolumn{3}{c}{ N.D. : not detected } \\
& & \multicolumn{3}{c}{- not tested }
\end{tabular}

Table 2 Survival of the bacteria in the activated sludge mixed liquor

\begin{tabular}{rcccc}
\hline & \multicolumn{4}{c}{ Counts $(\mathrm{CFU} / \mathrm{ml})$} \\
\cline { 2 - 5 } Time (hrs) & 0 & 3 & 8 & 24 \\
\hline E. coli O157 : H7 & & & \\
RUN 1 & N.D. & N.D. & N.D. & N.D. \\
2 & $6.4 \times 10^{4}$ & - & $4.5 \times 10^{3}$ & $7.5 \times 10^{2}$ \\
\multicolumn{1}{c}{ Fecal coliforms } & & & & \\
RUN 1 & $1.8 \times 10^{4}$ & - & - & $0.7 \times 10^{3}$ \\
2 & $8.4 \times 10^{4}$ & - & $7.2 \times 10^{3}$ & $1.2 \times 10^{3}$ \\
Total coliforms & & & & \\
RUN 1 & $8.0 \times 10^{4}$ & - & - & $6.5 \times 10^{3}$ \\
2 & $1.5 \times 10^{5}$ & - & $1.4 \times 10^{4}$ & $9.2 \times 10^{3}$ \\
\hline & & & N.D. : not detected
\end{tabular}

Table 3 Survival of the bacteria in the stored sludge

\begin{tabular}{cccccccccc}
\hline & \multicolumn{7}{c}{ Counts $(\mathrm{CFU} / \mathrm{ml})$} \\
\cline { 2 - 9 } Time (days) & 0 & 1 & 4 & 14 & 30 & 60 & 70 & 90 & 150 \\
\hline E. coli O157 : H7 & & & & & & \\
RUN 1 & N.D. & N.D. & N.D. & N.D. & N.D. & N.D. & N.D. & N.D. & N.D. \\
2 & $1.4 \times 10^{3}$ & $7.5 \times 10^{2}$ & $1.6 \times 10^{2}$ & $5.5 \times 10$ & $<10$ & $<10$ & $<10$ & $<10$ & $<10$ \\
3 & $3.4 \times 10^{4}$ & $3.0 \times 10^{4}$ & $1.4 \times 10^{4}$ & $1.8 \times 10^{3}$ & $9.5 \times 10$ & $<10$ & $<10$ & $<10$ & $<10$ \\
& & & & & & & & \\
Fecal coliforms & & & & & & & & \\
RUN 1 & $5.0 \times 10^{3}$ & $3.0 \times 10^{3}$ & $1.8 \times 10^{3}$ & $1.3 \times 10^{3}$ & $4.5 \times 10^{2}$ & $3.0 \times 10^{2}$ & $2.5 \times 10^{2}$ & $6.0 \times 10$ & $<10$ \\
2 & $3.0 \times 10^{3}$ & $2.8 \times 10^{3}$ & $2.1 \times 10^{3}$ & $8.2 \times 10^{2}$ & $1.5 \times 10^{2}$ & $5.8 \times 10$ & $2.0 \times 10$ & $2.0 \times 10$ & $<10$ \\
3 & $7.8 \times 10^{4}$ & $4.1 \times 10^{4}$ & $2.5 \times 10^{4}$ & $6.4 \times 10^{3}$ & $3.5 \times 10^{2}$ & $6.0 \times 10$ & $4.0 \times 10$ & $2.5 \times 10$ & $<10$ \\
Total coliforms & & & & & & & & \\
RUN 1 & $2.0 \times 10^{4}$ & $1.6 \times 10^{4}$ & $8.2 \times 10^{3}$ & $6.2 \times 10^{3}$ & $2.5 \times 10^{3}$ & $4.4 \times 10^{2}$ & $3.7 \times 10^{2}$ & $7.0 \times 10$ & $<10$ \\
2 & $2.8 \times 10^{4}$ & $2.2 \times 10^{4}$ & $1.2 \times 10^{4}$ & $4.2 \times 10^{3}$ & $5.8 \times 10^{2}$ & $1.8 \times 10^{2}$ & $4.0 \times 10$ & $3.0 \times 10$ & $<10$ \\
3 & $2.1 \times 10^{5}$ & $1.3 \times 10^{5}$ & $6.5 \times 10^{4}$ & $3.1 \times 10^{4}$ & $9.6 \times 10^{2}$ & $2.3 \times 10^{2}$ & $1.3 \times 10^{2}$ & $5.0 \times 10$ & $<10$ \\
\hline
\end{tabular}

N.D. : not detected

E. coli $\mathrm{O} 157: \mathrm{H} 7$, which suggests that coliforms may give a similar decline curve.

From Table 2, by comparing the bacteria concentrations about RUN 1, which was composed with domestic wastewater and sludge, and RUN 2, which added E. coli 0157 bacteria solution to them, we calculated the proportions of the fecal coliforms and total coliforms that originated from the added $E$. coli 0157 bacteria. And at the beginning of the preparation, they were $78 \%$ and $47 \%$, respectively. But after a $24 \mathrm{hr}$ aeration they decreased to $42 \%$ and $29 \%$. In other words, the proportions of fecal coliform and total coliform of $E$. coli 0157 bacteria origin became low as the aeration went on. This showed that there was the trend that coliforms of domestic wastewater and sludge origin were difficult to decrease than $E$. coli 0157 bacteria origin.

It has been reported that pathogenic bacteria such as Vibrio cholerae ${ }^{3)}$ and Salmonella ${ }^{3), 4), 6)}$ in wastewater are removed by biological treatment in parallel with a high BOD removal efficiency. Curds et al. studied on some kinds of ciliated protozoa feeding upon bacteria ${ }^{13)}$ and proved the removal of $E$. $\operatorname{coli}^{14)}$ by protozoa in the activated sludge process. And they explained that predation by protozoa such as Epistylis sp. and Aspidisca 
sp. inhabitting the activated sludge was most important. Also, Yaziz et al. ${ }^{6}{ }^{\prime}$ proposed the model of the removal of Salmonella enteritidis in activated sludge. They supported the theory of predation by ciliated protozoa, and demonstrated the protozoa played a major role in removing bacteria from the mixed liquor. In our experiments, these mechanisms may probably relate to $E$. coli O157:H7 removal by activated sludge. The scale of domestic wastewater treatment systems in Japan ranges from gappei-shori Johkasous designed for 5 users to sewage treatment facilities designed for tens of thousands of users. The initial concentration of $E$. coli $0157: \mathrm{H} 7,10^{4} \mathrm{CFU} / \mathrm{ml}$, was determined on the assumption that it entered a small-scale facility. Therefore, at large-scale facilities, where the concentrations of bacteria in the reactors are low because of the dilution with wastewater, the removal may require less time than our results. The results of this experiment suggest that biological treatment can almost completely remove the bacteria at most facilities. Generally, the aeration time should be more than $8 \mathrm{hrs}$ for conventional

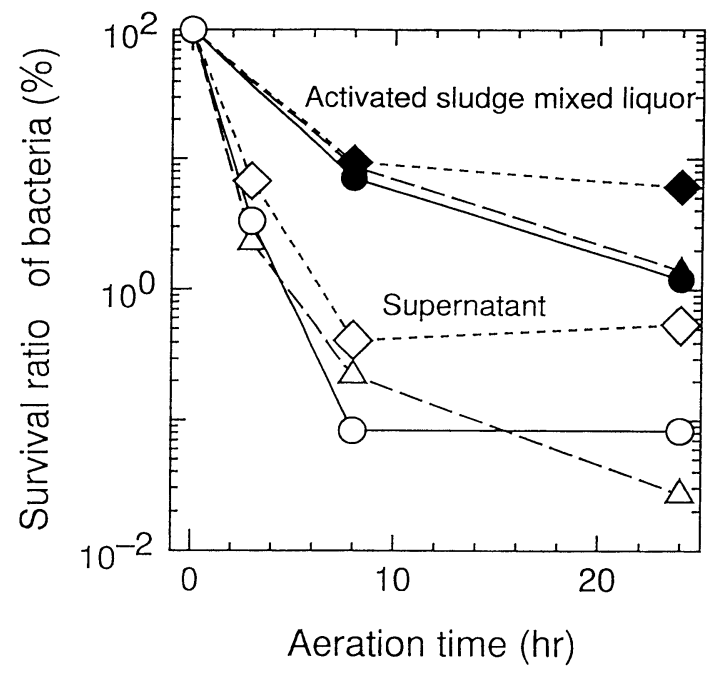

Fig. 2 The survival ratio of bacteria in the activated slude system (RUN 2). Symbols : $\bigcirc$, E. coli $0157: \mathrm{H7}$;

$\triangle$, fecal coliforms

$\diamond$, total coliforms

, E. coli 0157 : $\mathrm{H7}$;

$\Delta$, fecal coliforms;

$\checkmark$, total coliforms activated sludge process or more than $16 \mathrm{hrs}$ for extended aeration processes. Biologically treated water is disinfected with chlorine before discharge. Therefore E. coli $\mathrm{O} 157$ in water-borne need hardly be worried about if residual chlorine can be detected in the effluent.

On the other hand, Fig. 2 demonstrates $E$. coli O157:H7 still survived in the activated sludge mixed liquor after a $24 \mathrm{hr}$ aeration period at a survival ratio of more than $1 \%$ of the bacteria. In conventional wastewater treatment facilities, the sedimentary sludge in a clarifier or sedimentation tank is continuously returned to biological reactors. Therefore, once contamination by $E$. coli O157:H7 breaks out, it will last for a long time in the biological reactor, and $10^{2} \sim 10^{3} \mathrm{CFU} / \mathrm{ml}$ of $E$. coli $\mathrm{O} 157: \mathrm{H} 7$ (see Table 2, 3 ) will be left in the excess sludge.

Effect of sludge storage Figure 3 shows the survival ratio of bacteria in the stored sludge. The existence of each bacteria declined with time. The survival ratio of $E$. coli 0157:H7 decreased to $1 \%$ in about 30 days and was stable thereafter. Fecal coliforms and total coliforms required 150 days to be almost completely removed.

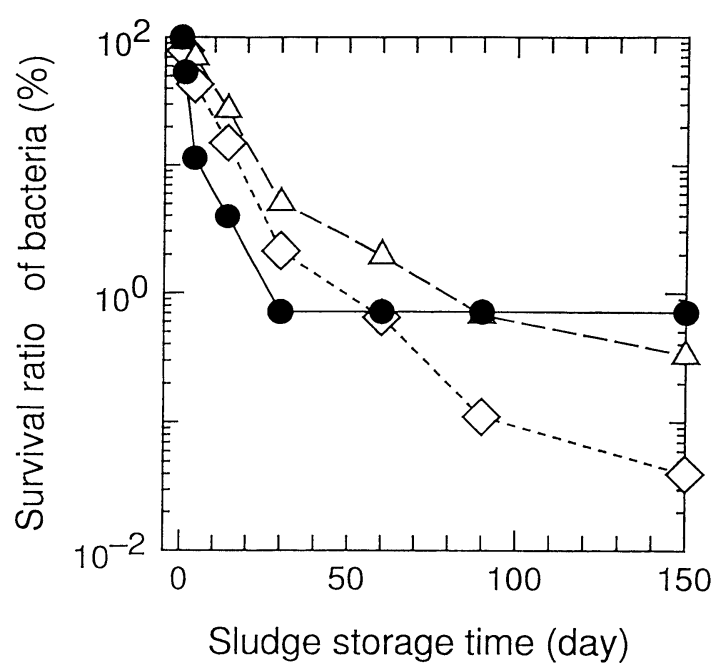

Fig. 3 The survival ratio of bacteria in the stored sludge (RUN 2)

Symbols : O, E. coli 0157 : H7;

$\triangle$, fecal coliforms;

$\diamond$, total coliforms 
As described above, it was proved that $E$. coli $0157: \mathrm{H} 7$ and coliform bacteria were able to survive in the sludge for a long time. The putrefaction, being acidified the sludge during more than a month's storage in anoxic condition, might be one of the reasons for the steady decline of the bacteria. It has been reported that $V$. cholerae survived for 13 days at $30^{\circ} \mathrm{C}$ after being added to excess sludge at the level of $10^{4} \mathrm{CFU} / \mathrm{m} l^{2)}$, and that Salmonella sp. and fecal coliforms survived at a high level in the stored sewage sludge after a year ${ }^{6}$. These examples can not easily be compared with our results because of differences in most suitable conditions for each bacterium. It may be estimated, however, that pathogenic microorganisms survive for considerably long time in sludge containing a high concentration of organic matter ${ }^{15), 16)}$. This suggests that the treatment of excess sludge needs aerobic thermophilic digestion ${ }^{17)}$ or composting ${ }^{18)}$.

Escherichia coli 0157:H7 profiles in domestic wastewater treatment facility

Figure 4 shows the case study which is led from this experiments. We set up the model if $E$. coli $\mathrm{O} 157: \mathrm{H} 7$ contamination occurs in the domestic wastewater at the level of $10^{4} \sim 10^{5}$ $\mathrm{CFU} / \mathrm{m} l$ and enters into a treatment facility using the extended aeration process. In the aeration tank, where MLSS is about 3,000 $\mathrm{mg} / l, 200 \mathrm{mg} / l$ of BOD in the influent will be removed efficiently and decrease to under 10 $\mathrm{mg} / \mathrm{l}$ in the effluent after the $24 \mathrm{hr}$ aeration period. Along with that, the number of $E$. coli O157:H7 will also decrease and may be under $10 \mathrm{CFU} / \mathrm{m} l$ in the effluent. And $E$. coli $\mathrm{O} 157: \mathrm{H} 7$ in the excess sludge which is 0.5 $\%$ volume of influent will survive at the level of $10^{2} \sim 10^{3} \mathrm{CFU} / \mathrm{ml}$. In the beginning the bacteria levels at the sludge thickening or storage tank will increase a little by thickening. But one month later $E$. coli O157:H7 in the storage sludge will be almost completely removed.

\section{CONCLUSIONS}

Domestic wastewater containing about $10^{4}$ $\mathrm{CFU} / \mathrm{m} l$ of $E$. coli $0157: \mathrm{H} 7$ was treated with activated sludge (MLSS was $2,500 \mathrm{mg} / l$ ) at $25^{\circ} \mathrm{C}$. Consequently, E. coli $0157: \mathrm{H} 7$ was almost completely removed from the supernatant after an $8 \mathrm{hr}$ aeration, and fecal coliforms and total coliforms were reduced considerably. Although the bacteria in the activated sludge mixed liquor decreased with aeration time, E. coli $0157: \mathrm{H} 7$ still survived after 24 hrs. Escherichia coli $0157: \mathrm{H} 7$ was almost completely removed from the stored sludge after 30 days while for fecal coliforms and total coliforms it took up to 150 days.

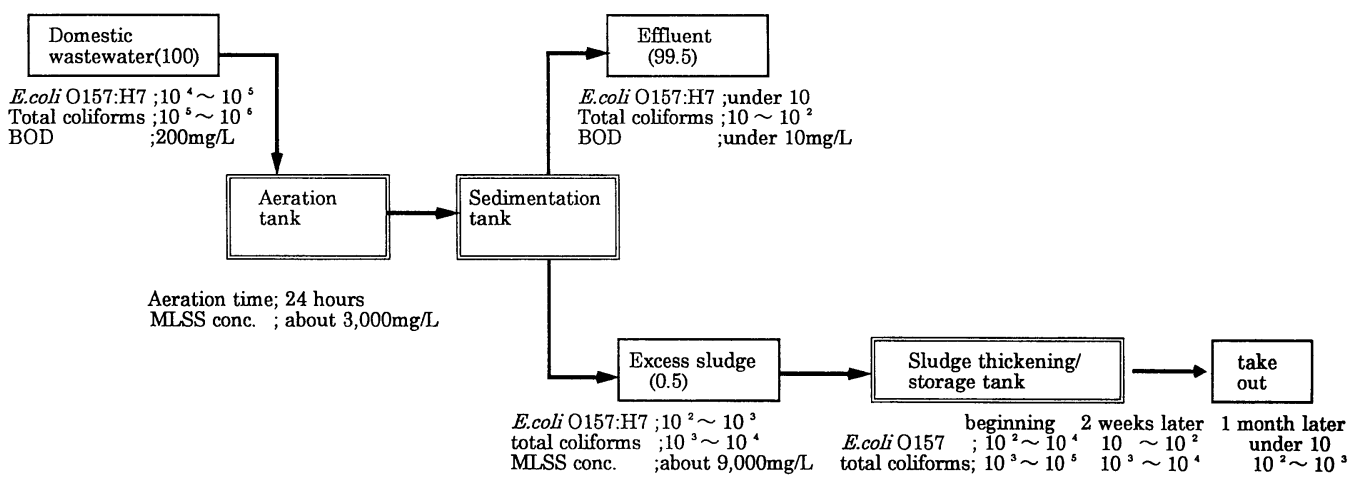

Note: unit for bacteria is $\mathrm{CFU} / \mathrm{mL}$

figures in parentheses show percentage of quantity

Fig. 4 A model for $E$. coli $0157: H 7$ removal in domestic wastewater treatment facilities using aeration process. 


\section{REFERENCES}

1 ) Ministry of Health and Welfare : Statistics on food poisoning (in Japanese), Association of Welfare Statistics (1998)

2) Koiwai K., Sanbe K., Nakayama K., Naritomi T., Yosida Y., and Nanahara Y.: Fate of Vibrio cholerae in the laboratory model of septic tank(in Japanese), Japanese Journal of Public Health, 31, 6, 250-256 (1984)

3 ) Kawamura K. and Kaneko M. : Microbial quality of human wastes and treatment plant's effluents, IAWPRC's first asian conference, Treatment disposal and management of human wastes,1-3 October (1985)

4) Kampelmacher E.H., van N.Jansen L.M. : Salmonella - its presence in and removal from a wastewater system, Jour.of Water Pollution Control Federation, 42, 2069 -2073 (1970)

5 ) Lewin V.H., Jones P.W., and Redhead D.L. : The fate of bacterial pathogens in sewage treatment processes, Water Pollution Control, 80, 42-51 (1981)

6) Yaziz M.I. and Lloyd B.J.: The removal of Salmonella enteritidis in activated sludge, Journal of Applied Bacteriology, 53, $169-172$ (1982)

7 ) Gibbs R.A., Hu C.J., Ho G.E., Phillips P. A., and Unkovich I. : Pathogen die-off in stored wastewater sludge, Water Science and Technology, 31, 5-6, 91-95 (1995)

8 ) Bito T. and Kitahara S.: A screening method for the isolation of Escherichia coli O157:H7 from water-borne(in Japanese), Japanese Journal of Water Treatment Biology, 28, 2, 89-93 (1992)

9) Pyle B.H., Broadway S.C., and Mefeters G.A.: A rapid direct method of enumerating respring enterohemorrhagic Escherichia coli O157:H7 in water, Applied and Environmental Microbiology, 61, 7, $2614-2619$ (1995)

10) Rice E.W., Johnson C.H., and Reasoner D. J. : Detection of Escherichia coli 0157: $\mathrm{H} 7$ in water from coliform enrichment cultures, Letters in Applied Microbiology,

\section{3, $179-182$ (1996)}

11) Wallace J.S. and Jones K.: The use of selective and differential agars in the isolation of Escherichia coli 0157 from dairy herds, Journal of Applied Bacteriology, 81, 663-668 (1996)

12) Manafi M. and Kneifel W.: A combined chromogenic-fluorogenic medium for the simultaneous detection of total coliforms and E. coli in water, Zentralblatt für Hygiene und Umweltmedizin, 189, 225 -234 (1989)

13) Curds C.R. and Vandyke J.M.: The feeding habits and growth rates of some fresh-water ciliates found in activated-sludge plants, Journal of Applied Ecology, 3, 127-137 (1966)

14) Curds C.R. and Fey G.J.: The effect of ciliated protozoa on the fate of Escherichia coli in the activated sludge process, Water Research, 3, 853-867 (1969)

15) Dudley D.J., Guentzel M.N., Ibbarra M.J., Moore B.E., and Sagik B.P.: Enumeration of potentially pathogenic bacteria from sewage sludge, Applied and Environmental Microbiology, 39, 118-126 (1980)

16) Farrah S.R. and Bitton G.: Bacterial survival and association with sludge flocs during aerobic and anaerobic digestion of wastewater sludge under laboratory conditions, Applied and Environmental Microbiology, 45, 174-181 (1983)

17) Berg G. and Berman D.: Destruction by anaerobic mesophilic and thermophilic digestion of viruses and indicator bacteria indigenous to domestic sludges, Applied and Environmental Microbiology, 39, 361 -368 (1980)

18) Shuval H., Jodice R., Consiglio M., Spaggiarri G., and Spigoni C.: Control of enteric microorganisms by aerobicthermophilic co-composting of wastewater sludge and agro-industry wastes, Water Science and Technology, 24, 2, 401-405 (1991)

(Submitted 1999. 6. 7) (Accepted 1999. 8. 14) 